\title{
Allergen Challenge Chamber: an innovative solution in allergic rhinitis diagnosis
}

\author{
Edyta Krzych-Fałta ${ }^{1}$, Jerzy Sowa², Oksana Wojas ${ }^{3}$, Barbara Piekarska $^{3}$, Adam Sybilski $^{3}$, Bolesław Samoliński ${ }^{1}$
}

\author{
${ }^{1}$ Department of Environmental Risk Prevention and Allergology, Faculty of Health Sciences, Medical University of Warsaw, Warsaw, \\ Poland \\ Head of the Department: Prof. Bolesław Samoliński MD, PhD \\ ${ }^{2}$ Faculty of Environmental Engineering, Warsaw University of Technology, Warsaw, Poland \\ Head of the Faculty: Prof. Marian Rosiński PhD \\ ${ }^{3}$ Unit of Environmental Hazard Prevention and Allergology, Faculty of Health Science, Medical University of Warsaw, Warsaw, Poland \\ Head of the Unit: Adam Sybilski MD, PhD
}

Postep Derm Alergol 2015; XXXII (6): 421-425

DOI: $10.5114 /$ pdia.2015.56096

\begin{abstract}
The Allergen Challenge Chamber (ACC) is definitely a serious challenge on the one hand and an innovative solution in allergic rhinitis diagnosis on the other. The gradual validation of the chamber (according to the test protocol) will allow for standardisation, which is a process undertaken by centres worldwide. The process of designing a consistent system that allows for creating conditions as those in the case of natural inhalation took into account all the aspects (technical specification) necessary to ensure appropriate inhalation.
\end{abstract}

Key words: Allergen Challenge Chamber, project.

\section{Introduction}

The mucous membrane of the nasal cavity produces mucus as the first barrier to protect the human body against the influence of bacteria, viruses, contamination or indoor and outdoor allergens. Long-lasting exposure to harmful factors results in the collapse of the immune system's first line of defence and the occurrence of inflammatory conditions. Undoubtedly, factors with the strongest influence on the occurrence of allergic diseases, including allergic rhinitis (defined as the inflammation of the nasal mucous membrane manifesting such symptoms as water discharge from the nose, nasal obstruction, itching, sneezing, discharge down the posterior wall of the pharynx in the case of very profuse water discharge from the nose) are indoor and outdoor allergens. The strongest inhalant allergens include grasses, weeds, trees (on average, $1-40 \%$ of allergic rhinitis cases are related to allergy to pollen), house dust mites and mould (1-13\% indicate the occurrence of chronic allergic rhinitis) [1]. Pollen (as the male reproductive cell) is borne by the wind mostly, and the type and quality of pollen are different in different weather conditions, geographical locations and temperatures [2]. Both in Poland and Europe, pollen is the most frequent cause of seasonal rhinitis [3]. The average size of a pollen seed is 10-100 $\mu \mathrm{m}$, which creates favourable conditions for pollen to deposit on the mucous membrane of the nose and in the conjunctival sac of the eye. For a typical picture of the symptoms of seasonal rhinitis, the concentration of pollen seeds in the air at $50 / \mathrm{cm}^{3}$ is sufficient [3]. Rapiejko and colleagues proved a close relationship between nasal symptoms and the average daily concentration of grass seeds in the air; 53 seeds/ $\mathrm{cm}^{3}$ in Warsaw (with considerable air pollution), 71 seeds/ $\mathrm{cm}^{3}$ in Masuria (with low air pollution) and 36 seeds $/ \mathrm{cm}^{3}$ in Katowice increase the risk of allergic symptoms. House dust mites are a group of saprophytic arachnids with the average length ranging from 0.1 to $0.5 \mathrm{~mm}$ and feeding on the human epidermis [4]. House dust allergens (Pyroglyphidae; Dermatophagoides pteronyssinus, Dermatophagoides farinae) measuring 10-20 $\mu \mathrm{m}$ in diameter are found mostly in stool lumps (enzymatic proteins found it their digestive tracts) [1]. On average, $2 \mu \mathrm{g}$ Der $\mathrm{p} 1$ per gram of dust is sufficient to cause allergic symptoms in children. This is equivalent to $0.6 \mathrm{mg}$ of guanine, while $10 \mu \mathrm{g}$ Der $\mathrm{p} 1$ per gram of dust raises the risk of asthma in non-allergic persons [5]. Mould spores (Alternaria ten-

Address for correspondence: Edyta Krzych-Fałta PhD, Department of Environmental Risk Prevention and Allergology, Faculty of Health Science, Medical University of Warsaw, 1a Banacha St, 02-097 Warsaw, Poland, phone: +48 225992039 , fax: +48 22 599 2042 , e-mail: e.krzych@gmail.com Received: 24.09.2014, accepted: 5.11.2014. 
uis, Cladosporium herbarum), due to their low molecular weight (3-10 $\mu \mathrm{m})$, are frequently responsible for the need to hospitalise patients diagnosed with co-existing bronchial asthma [6]. The most appropriate method for evaluating the human body's reaction to an allergen is the nasal challenge test with an allergen (NCT), defined as "a method for recovering the response of the upper airways to natural exposure to allergens or irritants and to do research into the pathophysiology of upper airway diseases by testing potential biochemical mediators" [7]. The nasal challenge test involves measuring the subject's subjective sensations and using measures of objective testing techniques which are subject to standardisation attempts (Table 1) and determined in the early (within $30 \mathrm{~min})$ and late (4-48 h) phases of the allergic reaction $[7,8]$.

The usefulness of the NCT in the differential diagnosis of allergic rhinitis is emphasised in numerous studies, and the specificity and sensitivity of the test, compared to the bronchial challenge test, are $93 \%$ and $98 \%$, respectively. In a group of patients with allergic rhinitis and bronchial asthma, the NCT yields positive results only in $32-58 \%$ of the patients (which indicates local production of IgE on the mucous membrane of the nasal cavity) [9].
In contrast, the negative result of the NCT with positive results of skin prick tests and slgE tests contributes to the development of allergic disease. The widely described phenomenon referred to as united airways (bronchial response (obstruction) to the NCT) exacerbates respiratory system disease, which reaction can be observed in the late phase of the test. The NCT is different from the natural process observed e.g. during the grass pollen season, where patients are continuously exposed to allergens, which contributes to the development of an advanced inflammatory condition and non-specific hyperactivity of the mucous membrane of the nasal cavity, with a dose (of $5000 \mu \mathrm{B} / \mathrm{ml}$ ) administered on a one-off basis, which is significantly higher than that during the pollen season [10]. Connell proved that the NCT performed at short intervals leads to what is referred to as the priming effect on the mucous membrane of the nasal cavity, and the dose necessary to cause the reaction was 10-100 times smaller than the standard one [11]. This is caused by the infiltration of eosinophils and increased blood flow through the (resistance) vessels of the nasal cavity.

\section{Aim}

It is therefore necessary to design and implement a method that can be used to objectively verify the stim-

Table 1. NCT measurement techniques [12]

\begin{tabular}{|c|c|}
\hline Objective and subjective techniques & Principle \\
\hline \multicolumn{2}{|r|}{ Subjective techniques } \\
\hline Bachert's scale of symptoms & $\begin{array}{l}\text { 0-3 points. The measurement covers the following nasal symptoms: nasal discharge, } \\
\text { sneezing, nasal patency, and the following non-nasal symptoms: eye watering, itching of } \\
\text { the palate, conjunctivitis, nettle rash, cough, breathlessness Hytonen }\end{array}$ \\
\hline VAS & $\begin{array}{l}\text { A } 10-\mathrm{cm} \text { horizontal line is used to measure, in percentage terms, the values of nasal } \\
\text { symptoms }\end{array}$ \\
\hline \multicolumn{2}{|r|}{ Objective techniques } \\
\hline Anterior rhinoscopy & $\begin{array}{l}\text { This method measures the level of swelling and the congestion of the mucous membrane } \\
\text { of the nasal concha }\end{array}$ \\
\hline Acoustic rhinometry* & $\begin{array}{l}\text { This is used to measure the nasal cavity by recording a picture of the cross-sections of the } \\
\text { nasal cavity }\end{array}$ \\
\hline Optical rhinometry* & $\begin{array}{l}\text { (Emission spectroscopy) This method measures changes in blood flow through blood vessels } \\
\text { and the oxygen saturation of haemoglobin }\end{array}$ \\
\hline Rhinomanometry* & $\begin{array}{l}\text { This measures the resistance of the air flowing through the nasal cavity by measuring the } \\
\text { volume of air in a unit of time and the difference in pressure levels between the posterior } \\
\text { nares and the anterior nares }\end{array}$ \\
\hline $\mathrm{PNIF}^{*}$ & $\begin{array}{l}\text { In this method, the subject breathes in as much air as he or she can into a specially designed } \\
\text { mask, with the mouth closed }\end{array}$ \\
\hline $\begin{array}{l}\text { Concentration of nitrogen oxide in the } \\
\text { air exhaled from the upper airways* }\end{array}$ & $\begin{array}{l}\text { The patient breathes out the air calmly against resistance (at least } 10 \mathrm{~cm} \mathrm{H}_{2} \mathrm{O} \text { ) in accordance } \\
\text { with the American Thoracic Society's principles }\end{array}$ \\
\hline $\begin{array}{l}\text { Concentration of reaction mediators, } \\
\text { including tryptase and ECP in the nasal } \\
\text { lavage fluid }\end{array}$ & This method measures the levels of inflammation mediators, e.g. Tryptase ECP \\
\hline
\end{tabular}

*Standardisation attempts. 
ulus - reaction observed under natural conditions in a continuous and controlled manner. The Allergen Challenge Chamber (ACC) is definitely a serious challenge on the one hand and an innovative solution in allergic rhinitis diagnosis on the other. The gradual validation of the chamber (according to the test protocol) will allow for standardisation, which is a process undertaken by centres worldwide (Table 2).

What are the benefits of the ACC?

- Controlled observation of the patient using objective and subjective techniques; the early and late phases of the allergic reaction.

- Observation and monitoring of the release of nasal inflammation mediators.

- Evaluation of the start and duration of the reaction as a result of allergen inhalation.

- Determination of the mucous membrane reactivity limit and the degree of symptoms.

- Observation not only with regard to the nose (lungs, conjunctivas; measurements using objective techniques).

- Evaluation of the effectiveness of specific immunotherapy.

- Evaluation of the effectiveness and safety of the effects of anti-allergy medicines.

- Possibility of taking measurements under any weather conditions.
- Minimisation of the costs of the test ( 6 subjects) compared to an individual NCT in an outpatient setting.

The process of designing a consistent system that allows for creating conditions as those in the case of natural inhalation took into account all the aspects (technical specification) necessary to ensure appropriate inhalation (Figure 1).

\section{Room topography and building materials}

The development plan for a clinical hospital in Warsaw locates an ACC on the first floor of the hospital building, in the central part of the corridor. The testing location will be a room of $12 \mathrm{sq} \mathrm{m}(3 \mathrm{~m} \times 4 \mathrm{~m}$, with a suspended ceiling), constructed of polyethylene sheets (floor thickness: $20 \mathrm{~mm}$, side wall thickness: $20 \mathrm{~mm}$, thickness of the suspended ceiling (where a ventilation system will be installed): $20 \mathrm{~mm}$ ) with antistatic properties that prevent the accumulation of allergens/pollen on the outer surface of the wall. Polyethylene sheets (Dehoplast ${ }^{\circledR}$ PE-1000 AST, modulus of elasticity: 700, specific surface resistance: $\left\langle 10^{9}\right.$ ) will be welded together, and the gaps between the sheets will be filled with polyethylene foam [13]. In addition, the entire ACC (Figure 1) will comprise: a changing room and a bathroom for the subjects (to minimise the risk of the allergen being carried on the

Table 2. Technical properties of inhalation allergen chambers (based on Day et al.) [12]

\begin{tabular}{|c|c|c|c|c|c|c|}
\hline Parameters & $\begin{array}{l}\text { VCC (Vienna } \\
\text { University } \\
\text { Clinic) [11] }\end{array}$ & EEU (UK) [12] & $\begin{array}{c}\text { Allergy Center } \\
\text { (Vienna) [13] }\end{array}$ & VCC (Copenhagen) [14] & $\begin{array}{c}\text { VCC (Atlanta) } \\
{[15]}\end{array}$ & $\begin{array}{c}\text { VCC (Hannover) } \\
{[16]}\end{array}$ \\
\hline Area $\left[\mathrm{m}^{2}\right]$ & 13.78 & 303 & 21 & 5 & 360 & 47 \\
\hline Height [m] & 2.7 & 2.74 & 2.8 & 2.6 & 3.6 & 2.8 \\
\hline $\begin{array}{l}\text { Number of } \\
\text { subjects }\end{array}$ & 14 & 160 & 24 & 1 & 150 & $18-25$ \\
\hline Type of room & $\begin{array}{c}\text { A custom } \\
\text { designed room }\end{array}$ & $\begin{array}{l}\text { A custom } \\
\text { designed room } \\
\text { in a hospital }\end{array}$ & $\begin{array}{c}\text { A custom } \\
\text { designed room }\end{array}$ & A portable tent & $\begin{array}{c}\text { A custom } \\
\text { designed room }\end{array}$ & $\begin{array}{c}\text { A custom } \\
\text { designed room }\end{array}$ \\
\hline $\begin{array}{l}\text { Ventilation } \\
\text { system }\end{array}$ & $\begin{array}{l}\text { Air pumped } \\
\text { into the room } \\
\text { through } \\
\text { a ceiling- } \\
\text { mounted system } \\
\text { and removed } \\
\text { through the floor }\end{array}$ & $\begin{array}{c}100 \% \text { of } \\
\text { outdoor air } \\
\text { filtered by Farr } \\
30 / 30 \text { and Farr } \\
\text { Riga-Flo } 200 \\
\text { filters }\end{array}$ & $\begin{array}{l}\text { Air pumped } \\
\text { into the room } \\
\text { through a ceiling- } \\
\text { mounted system } \\
\text { and removed } \\
\text { through the floor }\end{array}$ & $\begin{array}{c}\text { Vent filters, application } \\
\text { of an allergen by means } \\
\text { of a diffuser at a rate of } \\
4000-6000 \mathrm{l} / \mathrm{h}\end{array}$ & $\begin{array}{c}\text { Outdoor } \\
\text { ventilation } \\
\text { at a rate of } \\
\geq 5 \mathrm{cfm} / \text { person }\end{array}$ & $\begin{array}{l}\text { Outdoor } \\
\text { ventilation with } \\
\text { a HEPA filter }\end{array}$ \\
\hline Dose & $\begin{array}{c}1500 \text { seeds } / \mathrm{m}^{3} \\
\left(700-110 \mathrm{ng} / \mathrm{m}^{3}\right) \\
20-110 \mathrm{ng} / \mathrm{m}^{3} \\
\text { Der p } 1\end{array}$ & $\begin{array}{c}3500 \pm 500 \\
\text { seeds } / \mathrm{m}^{3}\end{array}$ & $\begin{array}{c}1400 \text { seeds/m³ } \\
90 \text { ng/m } \text { m }^{3} \text { Der p } 1\end{array}$ & 50-100 ng/m³ Der p 1 & $\begin{array}{l}3000-4500 \\
\text { seeds } / \mathrm{m}^{3}\end{array}$ & $\begin{array}{l}1000-8000 \\
\text { seeds } / \mathrm{m}^{3}\end{array}$ \\
\hline $\begin{array}{l}\text { Allergen } \\
\text { concentration } \\
\text { monitoring } \\
\text { method }\end{array}$ & $\begin{array}{l}\text { Bucard device, } \\
\text { every } 5 \text { min }\end{array}$ & $\begin{array}{l}\text { Rotorom } \\
\text { device, every } \\
30 \text { min }\end{array}$ & Every $5 \mathrm{~min}$ & $\begin{array}{c}\text { A portable measurement } \\
\text { device installed in the } \\
\text { filter }\end{array}$ & $\begin{array}{l}\text { Bucard device, } \\
\text { every } 30 \text { min }\end{array}$ & $\begin{array}{c}\text { Rotorom device, } \\
\text { every } 30 \text { min; } \\
\text { a particle } \\
\text { counter laser } \\
\text { device, every } \\
\text { minute }\end{array}$ \\
\hline
\end{tabular}




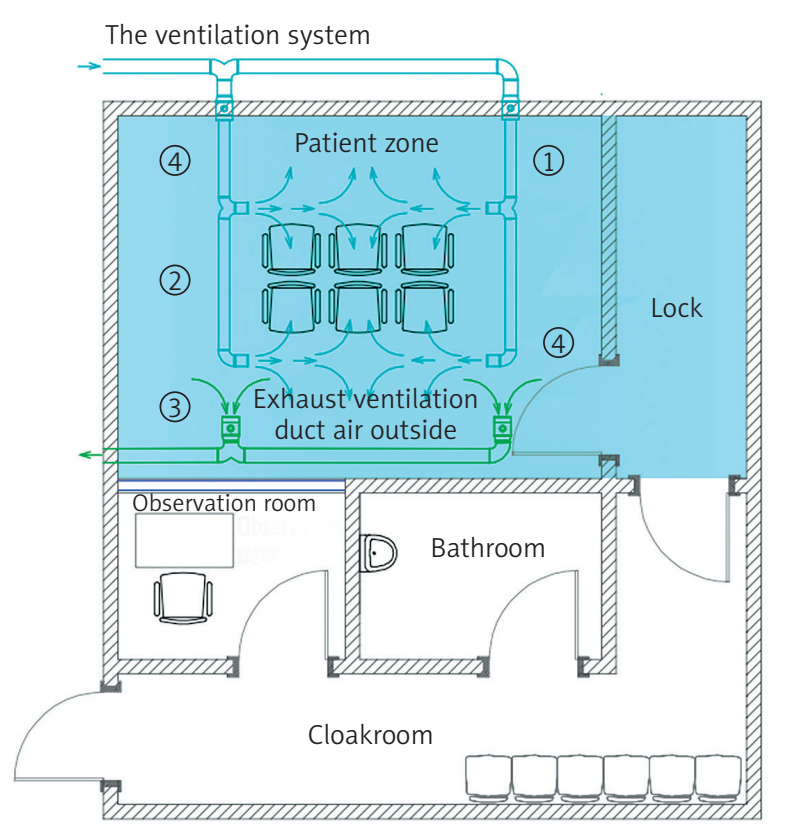

Exclusion zone

(1) VPPT 2000 pollen trap

(2) Higrometr

(3) Thermometer

(4) Bucard pollen trap

Figure 1. ACC project

outer surface of the subjects' clothes; after taking a bath in the bathroom, the patient will put on clothes washed, as a standard, in the hospital's central laundry, including a head protective cap), a sluice room as an extension of the closed zone, and an observation room (equipped with apparatus and an anti-shock first aid kit in accordance with the procedures in place at the hospital).

\section{The ventilation system}

The ventilation system should ensure, as far as possible, the same concentration of the applied allergen in the whole area used by people. Maximum air tightness of the chamber should be ensured so that the air is supplied to and removed from the testing room during the test only by means of the mechanical ventilation system. The system should prevent the release of the applied allergens from the testing room into the adjacent rooms and the surrounding area. There will be six chairs in the central part of the room, in the air supply zone. Each of the subjects will receive a hard copy version of the visual analogue scale (VAS) to be able to measure their subjectively perceived sensations during the test. The chamber will not be equipped with any computers or other unnecessary equipment as these are a potential source of heat. Doctor-patient communication will be ensured through a microphone. The chamber is designed for up to 6 people at a time. A separate mechanical supply and extract ventilation system will be designed for the purpose of the inhalation chamber. Additionally, the chamber will be equipped with an air conditioner to maintain the desired temperature levels irrespective of when the test is carried out. It is assumed that the ventilation system will supply outdoor air at a rate of $180 \mathrm{~m}^{3} / \mathrm{h}$ (i.e. $30 \mathrm{~m}^{3} / \mathrm{h}$ per person). The system will be designed to perform the following air treatment processes: air filtration (G4 class filter), heating (an electric duct heater), air pumping (a duct axial fan) and high efficiency filtration using a HEPA filter with a prefilter. The air will be supplied at the top of the room and extracted at the bottom. The air will be supplied through ceiling-mounted swirl diffusers and extracted through vent grates fitted on the wall at the bottom of the room. The extract section of the system will include, apart from the fan, a HEPA filter with a prefilter. The system will not recover heat from the extracted air, as it is economically unreasonable given the limited period of using the ventilation system. In the process of designing the system, the location of the fresh air inlet and the location of the exhaust air outlet will be carefully considered to minimise the risk of unintentional recirculation of the exhaust air. During the work to adapt the existing room to be used as an inhalation chamber, room pressure tests will be performed using the blower door method. This will allow for identifying and eliminating uncontrolled air flow paths (pollution migration paths). The use of a ceiling-mounted indoor cassette-type air conditioning unit is recommended to additionally increase the intensity of air mixing in the room, as this will help to ensure the same concentration of the applied allergens in the whole room.

\section{Nebuliser and the allergen dose}

The system should provide effective allergen filtration to prevent allergens from entering the testing room in the outdoor air coming into the room. The 'dry' air supply diffuser will be equipped with a measuring device to diffuse the dose at a rate of 4000-6000 l/min in the pollen exposure test. In the 'wet' diffusion part, an ultrasound nebuliser (Tajfun2 MU2) will be used to diffuse an allergen (Allergopharma) in the ACC. The allergen concentration monitoring method discussed in section 5 will be based on the HIALINE (Health Impacts of Airborne Allergen Information Network) programme.

\section{Additional equipment}

Additional equipment to measure temperature (21$\left.24^{\circ} \mathrm{C}\right)$, pressure $(60 \mathrm{~Pa})$ and air humidity (40-60\%) levels.

\section{Monitoring the concentration of the allergen in the air inside the chamber}

During the experiments, the parameters of the air inside the chamber should be stable as far as practicable. The concentration of the allergen in the air inside 
the chamber will be measured using the VPPT 2000 device manufactured by Lanzoni \& Bucard. The device is equipped with a tape that moves at a speed of $2 \mathrm{~mm}$ per hour, sucking in $10 \mathrm{l}$ of air per minute. The tape is cut in sections and coloured with fuchsine to measure the pollen seeds accumulating on the surface of the tape. The result of the measurement is the number of seeds in one cubic metre of air. The measurement will be repeated at 5-minute intervals. The HEPA filters in the air exhaust system will clean the air on the one hand and control the allergen level on the other (controlling, for example, the level of saprophytes for further measurements using the ELISA immunoenzyme method). Alternate measurements of the allergens/pollen dispersed by the ventilation systems at equal time intervals (14 days between sessions, in accordance with the test protocol) as part of the ACC validation process will allow for determining the threshold value to be achieved in order to cause the desired reaction in the patient during the test.

\section{Procedure for keeping the testing room clean and eliminating allergens from the testing room after each testing session}

Every time the testing room is washed, for $2 \mathrm{~h}$, with a cleaning agent (Glostrup, Ajax) that is neutral to allergy patients and causes no abrasion to the surface of ceilings, walls and floors made of polyethylene sheets, the testing room will be ventilated by supplying fresh air cleaned by HEPA filters, while keeping closed air circulation for $45 \mathrm{~min}$. An additional analysis of the HEPA filters or of samples collected from the surface of the walls, floor and ceiling of the testing room with the use of a transparent tape and placed on a standard microscopic slide for observation under a light microscope will allow for verifying the degree of allergen elimination from the chamber [13].

\section{Test report}

The need to design and implement the ACC solution is justified for many reasons as mentioned earlier. In addition, given the risk of the so-called underdiagnosed bronchial asthma, whose cause-and-effect relationship with allergic rhinitis has been proved in many studies (by Blair and Settipane: the symptoms of allergic rhinitis are more frequent in patients with bronchial asthma (28-78\%) than in subjects without asthma symptoms (5-20\%). In their study involving the use of an ECRHS questionnaire, Leynaert et al. found asthma without rhinitis in $1-6 \%$ of the subjects and asthma with rhinitis in 7.6-22.6\% of the subjects), the need to develop a golden standard for early diagnosis of such cases is additionally emphasised [14-17].

\section{Conflict of interest}

The authors declare no conflict of interest.

\section{References}

1. Bousquet J. Khalataev N, Alvaro A, et al. Allergic Rhinitis and its Impact on Asthma (ARIA) 2008. Alergia Astma Immunol Klin 2008; 13 (Suppl. 1): 3-39.

2. Bauchau V, Durham SR. Epidemiological characterization of the intermittent and persistent types of allergic rhinitis. Allergy 2005; 60: 350-3.

3. Rapiejko P, Weryszko-Chmielewska E. Pyłek traw. Alergia Astma Immunol 1998; 3: 187-92.

4. Rapiejko P. Pyłkowina. In: Choroby alergiczne. Zawisza E, Samoliński B (eds). PZWL, Warsaw 1998; 172-90.

5. Sporik R, Holgate SP, Platts-Mills TA, et al. Exposure to mouse-dust mite allergen (Der Pt) and the development of asthma in childhood. A prospective study. N Eng J Med 1990; 323: $502-7$

6. Atkinson RW, Strachan DP, Andreson HR, et al. Temporal associations between daily counts of fungal spores and asthma exacerbations. Occup Environ Med 2006; 63: 580-90.

7. Samoliński B, Krzych-Fałta E. Definition of nasal provocation test and nasal allergen challenge, classification. Postep Derm Alergol 2010; 27: 166-9.

8. Samoliński B. Analiza wyników rynometrii akustycznej na potrzeby diagnostyki rynoalergologicznej. PZWL, Warsaw 1993.

9. Mazurek H, Modrzyński M, Krzych-Fałta E, et al. Nasal challenge tests with allergens versus other allergy and rhinitis diagnostic tests. Postep Derm Alergol 2010; 27: 193-5.

10. Samoliński B, Rapiejko P. The early reaction after nasal airway challenge with alergen. Postep Derm Alergol 2010; 27: 170-2.

11. Connell J. Quantitative intranasal pollen challenges. II. Effect of daily pollen challenge, environmental pollen exposure and placebo challenge on the nasal membrane. J Allergy 1968; 41: 123-9.

12. Day JH, Horak F, Briscoe MP, et al. The role of allergen challenge chambers in the evaluation of anti-allergic medication: an international consensus paper. Clin Exp Allergy Rev 2006; 6: 31-59.

13. Rønborg SM, Mosbech H, Johnsen CR, Poulsen LK. Exposure chamber for allergen challenge. The development and validation of a new concept. Allergy 1996; 51: 82-8.

14. Blair H. Natural history of childhood asthma: 20-year follow-up. Arch Dis Child 1997; 52: 613-9.

15. Settipane GA. Allergic rhinitis-update. Otolaryngology Head Neck Surg 1986; 94: 470-5.

16. Leynaert B, Neukirch C, Kony S, et al. Association between asthma and rhinitis according to atopic sensitization in a population-based study. J Allergy Clin Immunol 2004; 113: 86-93.

17. Samoliński B, Sybilski A. Znaczenie stanów zapalnych błony śluzowej nosa w astmie oskrzelowej. Wspótistnienie alergicznego nieżytu nosa i astmy oskrzelowej. Alergia Astma Immunologia 2007; 12: 7-24. 